\title{
Mycoflora of fresh shrimps (Penaeus aztecus) from different markets in Port Harcourt, Nigeria
}

\author{
Obire, $\mathbf{O}^{1}$, Okigbo ${ }^{2}$, R. N. ${ }^{*}$ and Minimah, T. R. ${ }^{1}$ \\ ${ }^{1}$ Department of Applied and Environmental Biology, University of Science and Technology, P.M.B. 5080, Port Harcourt, \\ Nigeria. \\ ${ }^{2}$ Department of Botany, Nnamdi Azikiwe University, Awka, Nigeria.
}

Accepted 21 October, 2009

\begin{abstract}
Fungi were isolated from fresh brown shrimps (Penaeus aztecus) purchased from three different markets in Port Harcourt using standard mycological methods. The total counts of heterotrophic fungi range from $2.0 \times 10^{4}$ spore forming units per gram $(\mathrm{sfu} / \mathrm{g})$ to $7.1 \times 10^{4} \mathrm{sfu} / \mathrm{g}$, while the total counts for pathogenic fungi range from $1.7 \times 10^{4} \mathrm{sfu} / \mathrm{g}$ to $7.1 \times 10^{4} \mathrm{sfu} / \mathrm{g}$. The heterotrophic fungi and their percentage occurrence in the head, exoskeleton and telson/uropod $(H / E / T)$ before deterioration and about deterioration were: Aspergillus clavatus (20\%), Aspergillus flavus (20\%), Penicillium sp. (20\%), Rhizopus sp. (20\%), Rhodotorula sp. (20\%), Mucor hiemalis (14.3\%), Penicillium sp. (14.3\%), Rhizopus sp. (14.3\%), Rhizopus stolonifer (14.3\%), yeast sp. (14.3\%). While the pathogenic fungal occurrence before deterioration and about deterioration in the H/E/T were: A. clavatus (11.1\%), A. flavus (22.2\%), Penicillium sp. (33.3\%), Rhizopus oryzae (11.1\%), Rhodotorula sp. (11.1\%), yeast sp. (11.1\%), and $A$. clavatus (12.5\%), A. flavus (12.5\%), M. hiemalis (12.5\%), Penicillium sp. (12.5\%), Rhodotorula sp. (12.5\%) and yeast sp. (37.5\%). The presence of these fungi in the shrimps is attributed to contamination from the environment and from shrimp handlers (mongers). Also, some of these fungi are normal flora of the shrimp which unfortunately happens to be opportunistic pathogens or pathogens of humans. The maintenance of high personal and environmental hygiene as well as proper heating and cooking will improve fresh shrimp quality and prevent food-borne diseases.
\end{abstract}

Key words: Shrimps, contamination, pathogenic fungi, food-borne diseases.

\section{INTRODUCTION}

Brown shrimp is a small free-swimming edible crustacean with 10 legs. It is basically marine commonly found in estuaries and along coastal waters. However, its primary habitat is muddy bottom areas from inter tidal zone to approximately $110 \mathrm{~m}$ with greatest density occurring at depth between 27 to $55 \mathrm{~m}$ (Williams, 1984).

Brown shrimps are scavengers generally termed bottom-feeding opportunistic omnivores, which means they feed on most organic materials- dead plant or animal matter that they encounter at the bottom. They consume some algal species (that is, filamentous green algae, benthic diatoms, plant detritus), invertebrates such as copepods, mollusks, and annelids (Dall, 1968; Odum and Herald, 1972). Shrimps between the sizes of 65 to 100 $\mathrm{mm}$ in length became predatory, feeding on annelid worms, amphipods, zooplankton larvae, and nematodes (Jones, 1973).

These edible crustaceans are composed of $41 \%(\mathrm{w} / \mathrm{w})$ 
high value protein and omega- 3 fatty acids which have anti-inflammatory effects and are able to prevent the formation of blood clots). They are also important sources of vitamin D and B12 needed to keep low levels of homocysteine - a molecule that can directly damage blood vessel walls and is considered a significant risk factor for cardiovascular diseases.

Shrimps, apart from being of great nutritional value to the consumer; also serves as an ideal culture medium for microbial growth, which connotes spoilage. Despite all the benefits associated with shrimps, one thing still remains clear and yet unsolved; shrimps are highly prone or susceptible to rapid deterioration immediately after harvest.

Microorganisms are undoubtedly responsible for spoilage of shrimps and these microorganisms include bacteria and fungi, both the heterotrophic and pathogenic forms. One important characteristic of microbes is that, they grow rapidly and increases in number (Harrigan and McCance, 1990). Molds which belongs to fungi, grows rapidly on food (shrimp) when held under moist conditions. These organisms take advantage of the moist condition available and through the aid of enzymes which they possess, they weaken and penetrate the protective outer layer of the shrimp and cause spoilage (Donald et al., 1999).

It is almost always possible to detect a range of human pathogens on any shrimp that has not received any microbiocidal treatment (Okigbo and Ajalie, 2005). Some of these pathogens may constitute part of the normal flora on the shrimp or be present as a result of unavoidable contamination (ICMSF, 1996). Also, a normal microflora of humans can cause spoilage of shrimp by way of contamination through handlers, as they touch the shrimp with bare hands in the bid of harvesting and selling the shrimps. Also shrimp spoilage based on microbial origin, originates mainly from the shrimp's environment (which is aquatic) and in this environment, contamination may occur as a result of the presence or introduction of microorganisms through faecal means into the water bodies.

Fresh brown shrimps sold in the common markets in Port Harcourt do not undergo any form of microbiocidal treatment, and they are not iced before sale. The shrimp mongers also handle them with bare hands during transactions. Some shrimp consumers cook the shrimps whole (that is, including the head, exoskeleton and telson/uropods); others remove the head, exoskeleton and telson/uropods of the shrimps before cooking (only flesh) while some consumers after removing the head, exoskeleton and telson/uropods, grind them and add the paste to the soup or sauce.

There is therefore the need to ascertain the microorganisms (fungi) associated with these various parts of shrimps and the health hazards associated with the types of microorganisms. The knowledge of the types of microorganisms involved in their spoilage will also help to con- trol shrimp spoilage.

\section{MATERIALS AND METHODS}

\section{Sampling sites and collection of fresh shrimp samples}

Fresh shrimp samples were purchased from shrimp mongers in Creek Road Market, Town Market, and Mile One Market all in Port Harcourt Local Government Area of Rivers State. These markets were visited at about 7:30am on the days of collection of samples.

Disposable gloves were worn, before collection of the fresh shrimps from the tray into a sterile transparent plastic container containing ice. The plastic container was covered with its lid and transported immediately to the laboratory for analysis.

\section{Preparation of media and preparation of diluent}

Potato dextrose agar (PDA) and Sabouraud dextrose agar (SDA) media were used for isolation of fungi. Heterotrophic fungi were cultured on PDA and pathogenic fungi on SDA medium. Serial dilution plate method was adopted for isolation of fungi. Exactly $0.85 \mathrm{~g}$ of sodium chloride $(\mathrm{NaCl})$ was weighed and dissolved in 100 $\mathrm{ml}$ of sterile distilled water; $9 \mathrm{ml}$ of the normal saline was transferred into sterile lost tubes and autoclaved at $121^{\circ} \mathrm{C}$ for $15 \mathrm{~min}$ at 15 pounds/pressure and allowed to cool. The diluent was used to carry out serial dilution of the fresh shrimp samples. Normal saline was used as a diluent because it helps to reactivate stressed microorganisms.

\section{Cultivation and enumeration and isolation of fungi in the fresh shrimp}

The fresh shrimp samples were divided into two portions. One portion comprised the head, exoskeleton, and telson/uropod (HET) while the other portion was the flesh $(F)$. The samples were analyzed separately to have a thorough sampling study of the presence of fungi in the samples purchased from the three (3) different markets.

Each portion (sample) was separately ground in a sterile ceramic mortar and pestle. One gram $(1.0 \mathrm{~g})$ of each portion was transferred into $9 \mathrm{ml}$ of the normal saline and thoroughly shaken to make a 10 ${ }^{1}$ dilution. This dilution was further diluted serially up to the $10^{-3}$ dilution. This was done so as to obtain discrete colonies or colony forming units (CFU) when plated out on the different media for fungi.

From the $10^{-2}$ and $10^{-3}$ dilution, an aliquot $(0.1 \mathrm{ml})$ was collected aseptically onto separate freshly prepared PDA and SDA plates to which $0.2 \mathrm{ml}$ of $0.5 \%$ ampicilin was added to inhibit the growth of bacteria and allowing the growth of fungi (Harrigan and McCance, 1990). A sterile glass spreader was used to spread the inoculum evenly on the whole surface of the media. The cultured plates were also prepared in duplicates and inoculated plates were incubated at ambient temperature for three to five days. Colonies or spore forming units which developed on the PDA and SDA plates after five days were counted and the average count for duplicate cultures were recorded as total viable heterotrophic fungi and total viable pathogenic fungi in the sample, respectively. The colour and colonial morphologies or characteristics were also recorded.

Discrete colonies were subcultured onto freshly prepared PDA and SDA plates and incubated at $28^{\circ} \mathrm{C}$ for five to seven days to further purify the fungal isolates. The fungal spore forming units which developed were further subcultured onto agar slopes or slants and incubated at $28^{\circ} \mathrm{C}$ for five to seven days. The isolates 
Table 1. Total heterotrophic fungal count $(\mathrm{sfu} / \mathrm{g})$ of the shrimps from the markets.

\begin{tabular}{lcccc}
\hline \multirow{2}{*}{ Site } & \multicolumn{2}{c}{ Head, exoskeleton and telson } & \multicolumn{2}{c}{ Flesh } \\
\cline { 2 - 5 } & Before deterioration & About deterioration & Before deterioration & About deterioration \\
\hline Creek Road Market & $5.6 \times 10^{4}$ & $4.8 \times 10^{4}$ & $2.0 \times 10^{4}$ & $7.1 \times 10^{4}$ \\
Mile One Market & $6.6 \times 10^{4}$ & $3.1 \times 10^{4}$ & $6.8 \times 10^{4}$ & $4.6 \times 10^{4}$ \\
Town Market & $5.6 \times 10^{4}$ & $4.8 \times 10^{4}$ & $3.0 \times 10^{4}$ & $7.1 \times 10^{4}$ \\
\hline
\end{tabular}

Table 2. Pathogenic fungal count (sfu/g) of shrimps from the markets

\begin{tabular}{lcccc}
\hline \multirow{2}{*}{ Site } & \multicolumn{2}{c}{ Head, Exoskeleton and telson } & \multicolumn{2}{c}{ Flesh } \\
\cline { 2 - 5 } & Before deterioration & About deterioration & Before deterioration & About deterioration \\
\hline Creek Road Market & $6.4 \times 10^{4}$ & $4.8 \times 10^{4}$ & $1.7 \times 10^{4}$ & $5.1 \times 10^{4}$ \\
Mile One Market & $5.0 \times 10^{4}$ & $3.7 \times 10^{4}$ & $6.4 \times 10^{4}$ & $3.3 \times 10^{4}$ \\
Town Market & $6.4 \times 10^{4}$ & $4.8 \times 10^{4}$ & $1.7 \times 10^{4}$ & $7.1 \times 10^{4}$ \\
\hline
\end{tabular}

which developed were pure cultures which were stored in the refrigerator as stock cultures for subsequent characterization tests. Identification of fungal species was done with help of manuals of Barnett and Hunter (1972) and Malloch (1997).

\section{RESULTS}

\section{Evaluation of total heterotrophic fungi and total pathogenic fungal counts from the various markets}

The results of mean count of total heterotrophic and pathogenic fungi in the various portions of the shrimps from the markets are as shown in Tables 1 and 2, respectively.

Population of heterotrophic fungi per gram of head, exoskeleton and telson/uropod (HET) of shrimps from Creek Road market, Mile One market and Town market before deterioration, ranged from $5.1 \times 10^{4}$ to $6 \times 10^{4}$ $\mathrm{sfu} / \mathrm{g}, 4.1 \times 10^{4}$ to $6 \times 10^{4} \mathrm{~g}$ and $5.1 \times 10^{4}$ to $6 \times 10^{4} \mathrm{sfu} / \mathrm{g}$, respectively while counts about deterioration ranged from $1.0 \times 10^{4}$ to $3 \times 10^{4} \mathrm{sfu} / \mathrm{g}, 4.5 \times 10^{4}$ to $9 \times 10^{4} \mathrm{sfu} / \mathrm{g}, 1.0 \times$ $10^{4}$ to $5 \times 10^{4} \mathrm{sfu} / \mathrm{g}$.

The mean results of the total count of heterotrophic fungi per gram of flesh of shrimps from Creek Road market, Mile One market and Town market before deterioration ranged from $6.5 \times 10^{4}$ to $3 \times 10^{4} \mathrm{sfu} / \mathrm{g}, 4.1 \times 10^{4}$ to $2 \times 10^{4} \mathrm{cfu} / \mathrm{g}$, and from $6.5 \times 10^{4}$ to $3 \times 10^{4} \mathrm{sfu} / \mathrm{g}$ while fungal counts in flesh of shrimps about deterioration ranged from $5.1 \times 10^{4}$ to $9 \times 10^{4} \mathrm{sfu} / \mathrm{g}, 3.1 \times 10^{4}$ to $6.0 \times$ $10^{6} \mathrm{sfu} / \mathrm{g}$ and from $5.1 \times 10^{4}$ to $9 \times 10^{-4} \mathrm{sfu} / \mathrm{g}$, respectively.

The mean counts of the total pathogenic fungi per gram of head, exoskeleton and telson/uropod (HET) of shrimps from Creek Road market, Mile One market and Town market before deterioration ranged from $4.8 \times 10^{4} \mathrm{cfu} / \mathrm{g}$ to $8.0 \times 10^{4} \mathrm{cfu} / \mathrm{g}, 3.0 \times 10^{4} \mathrm{cfu} / \mathrm{g}$ to $7.0 \times 10^{4} \mathrm{cfu} / \mathrm{g}$ and from $4.8 \times 10^{4} \mathrm{cfu} / \mathrm{g}$ to $8.0 \times 10^{4} \mathrm{cfu} / \mathrm{g}$ respectively. While counts in HET of shrimps about deterioration ranged from
$3.6 \times 10^{4} \mathrm{cfu} / \mathrm{g}$ to $6.0 \times 10^{4} \mathrm{cfu} / \mathrm{g}, 1.4 \times 10^{4} \mathrm{cfu} / \mathrm{g}$ to $6.0 \times$ $10^{4} \mathrm{cfu} / \mathrm{g}$, and from $3.6 \times 10^{4}$ to $6.0 \times 10^{4} \mathrm{cfu} / \mathrm{g}$, respectively.

The mean results of the total count of pathogenic fungi per gram of flesh of shrimps from Creek Road market, Mile One market and Town market before deterioration ranged from $1.0 \times 10^{4}$ to $2.3 \times 10^{4} \mathrm{cfu} / \mathrm{g}, 4.1 \times 10^{4}$ to $8.0 \mathrm{x}$ $10^{4} \mathrm{cfu} / \mathrm{g}$, and from $1.0 \times 10^{4}$ to $2.3 \times 10^{4} \mathrm{cfu} / \mathrm{g}$, respectively. While counts in the flesh of the shrimps about deterioration ranged from $5.0 \times 10^{4}$ to $5.2 \times 10^{4}$ $\mathrm{sfu} / \mathrm{g}, 1.5 \times 10^{4}$ to $5.0 \times 10^{4} \mathrm{sfu} / \mathrm{g}$ and from $5.2 \times 10^{4}$ to $9.0 \times 10^{4} \mathrm{sfu} / \mathrm{g}$, respectively.

Analysis of variance (F-distribution) showed that generally, except for the fungal count in the flesh of the shrimps before deterioration which showed significant difference at $P \geq 0.05$ (with Mile One shrimps recording the highest counts); there is no significant difference in the fungal count of shrimps between the various markets.

The frequencies of occurrence (\%) of heterotrophic and pathogenic fungi in shrimps from the markets are as shown in Tables 3 and 4, respectively. The heterotrophic fungi and their percentage occurrence in the $\mathrm{H} / \mathrm{E} / \mathrm{T}$ (head, exoskeleton and telson/uropod) before deterioration and about deterioration were: Aspergillus clavatus (20\%), Aspergillus flavus (20\%), Penicillium sp. (20\%), Rhizopus sp. (20\%), Rhodotorula sp. (20\%), and Aspergillus flavus (28.6\%), Mucor hiemalis (14.3\%), Penicillium sp. (14.3\%), Rhizopus sp. (14.3\%), Rhizopus stolonifer $(14.3 \%)$, yeast sp. (14.3\%), respectively. While the pathogenic fungal occurrence before deterioration and about deterioration in the $\mathrm{H} / \mathrm{E} / \mathrm{T}$ were: $A$. clavatus (11.1\%), A. flavus (22.2\%), Penicillium sp. (33.3\%), $R$. oryzae (11.1\%), Rhodotorula sp. (11.1\%), yeast sp. $(11.1 \%)$, and $A$. clavatus $(12.5 \%)$, A. flavus $(12.5 \%)$, Mucor hiemalis (12.5\%), Penicillium sp. (12.5\%), Rhodotorula sp. (12.5\%) and yeast sp. (37.5\%), 
Table 3. Occurrence (\%) of heterotrophic fungi in shrimps from the markets.

\begin{tabular}{|c|c|c|c|c|}
\hline \multirow{2}{*}{ Fungus } & \multicolumn{2}{|c|}{ Head, exoskeleton and telson } & \multicolumn{2}{|c|}{ Flesh } \\
\hline & Before deterioration & About deterioration & Before deterioration & About deterioration \\
\hline Aspergillus clavatus & 20 & & & \\
\hline Aspergillus flavus & 20 & 28.6 & 33.3 & 22.2 \\
\hline Aspergillus niger & & & & 11.1 \\
\hline Mucor heimalis & & 14.3 & & \\
\hline Mucor plumbeus & & & & 11.1 \\
\hline Penicillium sp. & 20 & 14.3 & 33.3 & 22.2 \\
\hline Phialophora fastigiata & & & & 11.1 \\
\hline Rhizopus stolonifer & & 14.3 & & 11.1 \\
\hline Rhizopus sp. & 20 & 14.3 & & \\
\hline Rhodotorula sp. & 20 & & & 11.1 \\
\hline Yeast sp. & & 14.3 & 33.3 & \\
\hline
\end{tabular}

Table 4. Occurrence (\%) of pathogenic fungi in shrimps from the markets

\begin{tabular}{lcccc}
\hline \multirow{2}{*}{ Fungus } & \multicolumn{2}{c}{ Head, exoskeleton and telson } & \multicolumn{2}{c}{ Flesh } \\
\cline { 2 - 5 } & Before deterioration & About deterioration & Before deterioration & About deterioration \\
\hline Aspergillus clavatus & 11.1 & 12.5 & 28.6 & \\
$\begin{array}{l}\text { Aspergillus flavus } \\
\text { Aspergillus niger }\end{array}$ & 22.2 & 12.5 & & 10 \\
Mucor heimalis & & & & 10 \\
Mucor plumbeus & & 12.5 & 14.3 & 20 \\
$\begin{array}{l}\text { Penicillium sp. } \\
\text { Rhizopus oligosporus }\end{array}$ & 33.3 & 12.5 & 28.6 & 10 \\
Rhizopus oryzae & 11.1 & & & 11.1 \\
Rhizopus stolonifer & & & 14.3 & 10 \\
Rhodotorula sp. & 11.1 & 12.5 & & 20 \\
Yeast sp. & 11.1 & 37.5 & 14.3 & 20 \\
\hline
\end{tabular}

respectively. Heterotrophic fungi in the flesh before deterioration and about deterioration were, $A$. flavus (33.3\%), Penicillium sp. (33.3\%), yeast sp. (33.3\%) and Aspergillus flavus (22.2\%), Aspergillus niger (11.1\%), Mucor plumbeus (11.1\%), Penicillium sp. (22.2\%), Phialophora fastigiata (11.1\%), Rhizopus stolonifer (11.1\%) and Rhodotorula sp. (11.1\%) respectively. While the pathogenic fungal occurrence before deterioration and about deterioration in the flesh were Aspergillius flavus (28.6\%), Penicillium sp. (14.3\%), Rhizopus oligosporus (28.6\%), Rhizopus stolonifer (14.3\%), yeast sp. (14.3\%), Aspergillus niger (10\%), Mucor hiemalis (10\%), Mucor plumbeus (20\%), Penicillium sp. (10\%), Rhizopus stolonifer (10\%), Rhodotorula sp. (20\%), and yeast sp. (20\%) respectively

Among the heterotrophs isolated, only $A$. flavus and Penicillium sp. were isolated from the $\mathrm{H} / \mathrm{E} / \mathrm{T}$ and flesh, respectively in all three (3) markets. Among the Pathogenic fungi isolated from the $\mathrm{H} / \mathrm{E} / \mathrm{T}$ and flesh, only yeast sp., Penicillum sp., $R$. stolonifer, and $A$. flavus were isolated from the $\mathrm{H} / \mathrm{E} / \mathrm{T}$ in all three (3) markets, while others were isolated from either one or two of the three markets. Phialophora fastigiata was isolated from flesh of shrimp about deterioration from only Mile One market.

\section{DISCUSSION}

In the present study a number of fungal species recorded found to be associated with the head, exoskeleton, tail/telson $(\mathrm{H} / \mathrm{E} / \mathrm{T})$ and flesh of shrimps before and about deterioration. The different fungal genera isolated were Aspergillus, Mucor, Penicillium, Phialophora, Rhizopus, and yeast spp including Rhodotorula. These fungal genera appear to be associated with the spoilage of fresh shrimps. These fungi have also been associated with spoilage of fruits Okigbo and Obire, 2009).

The fungal counts recorded in the shrimps are considered very high ranging from $1.7 \times 10^{4} \mathrm{sfu} / \mathrm{g}$ to $7.1 \times 10^{4}$ 
sfu/g. Generally in all the markets, the population or mean count of total heterotrophic fungi in the H/E/T were higher before deterioration Except for Mile One market, counts were lower in the flesh of the shrimps before deterioration than about deterioration. The high fungal count is an indication of gross contamination of the environment where the shrimps were harvested and of the ecological niche where the fungi has developed. The results of both heterotrophic and pathogenic fungal counts were almost exactly the same in shrimps from the Creek Road and Town markets. This is not surprising because the distance between both markets is less than $200 \mathrm{~m}$; in-fact, they have virtually merged together. It is also a fact that shrimps from both market were harvested from the same environment. The isolation of Phialophora fastigiata from only Mile One market indicated that shrimps from this market were harvested from a different environment and hence the observed disparity in the fungal counts of shrimps from the three markets.

There was also an increase in the types of heterotrophic and pathogenic fungi in the shrimps about deterioration. These observations clearly indicate the utilization and exhaustion of nutrients in the shrimps and change in prevailing conditions such as $\mathrm{pH}$ which in turn resulted in the succession of fungi over time during deterioration of the shrimps

Among the pathogenic fungi isolated Aspergillus, Penicillium and yeast were more prevalent in $\mathrm{H} / \mathrm{E} / \mathrm{T}$ from all the markets, while Aspergillus flavus, Mucor, Rhizopus oligosporus and yeast sp. were prevalent in the flesh. Apart from some Rhizopus species frequency of isolation of the fungi were higher in the $\mathrm{H} / \mathrm{E} / \mathrm{T}$ than in the flesh of the shrimps. This shows that the presence of these fungi in the shrimps is as a result of direct contamination from the environment and shrimp handlers.

Statistical analysis showed that generally, except for the fungal count in the flesh of the shrimps before deterioration which showed significant difference at $P \geq 0.05$ (with Mile One shrimps recording the highest counts), there is no significant difference in the fungal count (heterotrophic and pathogenic) of shrimps between the various markets. This is a proof that pathogenicity of some fungi is not as a result of their numbers but in the production of mycotoxins as most of the isolates in this investigation produce mycotoxins.

The potential for disease outbreaks attributed to sea food ingestion has been recognized for over a century (Richards, 1985). It is important to state here that most of the fungi are potential pathogens. Some diseases caused by these fungi in humans are aspergillosis, liver tumor, fungal balls in the lungs, chronic productive cough and haemoptysis, bronchial asthma, infection of the ear or paranasal sinuses, fungal cells within histiocytes, necrosis and eventual abscess formation, multiple brain abscesses and Verucose dermatitis, a chronic human mycosis (Richards, 1985; Okigbo and Ajalie, 2005; Okigbo et al. 2009). Others include rhinocerebral mucor-mycosis, infection of the nasal turbates and paranasal sinuses spreading rapidly to the eyes and brain; necrosis and thrombosis and invasive mucormycosis (Singleton and Sainsbury, 2001).

\section{Conclusion and recommendation}

The presence of fungal species in the shrimps is also attributed to contamination from shrimp handlers or processors or sellers (mongers). The fungi isolated from the shrimps in this study are potential pathogens and they are capable of causing chronic illnesses in humans upon ingestion of food contaminated by them.

Owing to the health hazards associated with the fungi isolated from the brown shrimps used for this study, it is important that brown shrimps and other sea food product be properly and adequately cooked. Also unfavourable conditions should be created to prevent fungal growth, examples of such conditions are: regulation of the water holding capacity of the food $\left(\mathrm{a}_{\mathrm{w}}\right)$, temperature and $\mathrm{pH}$. Adjustments in these areas will help prevent mycotoxin contamination of the shrimp as moulds have strains which produce toxins that are capable of causing serious chronic illnesses (e.g. liver tumor caused by $A$. flavus) in humans, if consumed.

Being that some fungi contaminated the shrimps through shrimps handlers or processors, there is therefore the need for the adoption, practice, and maintenance of good personal hygiene as regards handling of the shrimp from the moment of catch till it reaches the consumer, so as to ensure good quality and long storage life of the shrimp. The maintenance of high personal and environmental hygiene as well as proper heating and cooking will improve fresh shrimp quality and prevent food-borne diseases.

\section{REFERENCES}

Dall W (1968). Food and Feeding of some Australian penaeid shrimp. Proc. World Science Conference on Bio. and Cult. Of shrimps and prawns. FAO Fisheries Reports 57(2): 251-258.

Harrigan WF, McCance ME (1990). Laboratory Methods in Food and Dairy Microbiology. $8^{\text {th }}$ Edition. Academic Press, London.

ICMSF (International Commission on Microbiology Specifications for foods) 1996. Microorganisms in Food 5. Characteristics of Microbial pathogens. Blackie Academy \& Professionals.

Jones RR (1973). Utilization of Louisiana estuarine seiments as a source of nutrition for the brown shrimps, Penaeus aztecus. Ph.D. Dissertation, Louisiana State University, Baton Rouge.

Malloch D (1997). Moulds Isolation, Cultivation and Identification, Department of Botany University of Toronto, Toronto USA.

Odum WE, Herald E (1972). Trophic analysis of an estuarine mangrove community. Bull. Mar. Sci. 22(3): 671-738.

Okigbo RN, Anuagasi CL, Amadi JE, Ukpabi UJ (2009). Potential inhibitory effects of some African tuberous plant extracts on Escherichia coli, Staphylococcus aureus and Candida albicans. Int. J. Integr. Biol. (India) 6 (2):91-98

Okigbo RN, Ajalie AN (2005). Inhibition of some human pathogens with tropical plants extracts Chromolinaena odorata and Citrus aurantifolia 
and some antibiotics. Int. J. Mol. Med. Adv. Sci. (Pakistan) 1 (1): 34 40.

Okigbo RN, Obire O (2009). Mycoflora and production of wine from fruits of soursop (Annona muricata L.) Int. J. Wine Res. (Auckland, New Zealand) 1: 1-9. Available online

at http://www.dovepress.com/articles.php?article id $=2731$

Richards GP(1985). Outbreak of shellfish-associated enteric virus illness in the United States: Requisite for development of viral guidelines. J. Food Prot. 48: 815 - 823.
Singleton P, Sainsbury D (2001). Dictionary of Microbiology and Molecular Biology. $3^{\text {rd }}$ Edn. John Wiley and Sons Ltd. New York. pp. 895.

Williams, A. B (1984). Shrimps, lobsters and crabs of the Atlantic coast of the Eastern United States, Marine to Florida. Smithsonian Institution Press. Washington, D C. pp. 550. 